\title{
Journalism in Change. Journalistic culture in Poland, Russia and Sweden
}

Gunnar Nygren \& Boguslawa Dobek-Ostrowska (red.)

Frankfurt am Main: Peter Lang GmbH 2016

333 sider. ISBN: 9783631649213

Anmeldt af Morten Skovsgaard [ph.d., lektor, Center for Journalistik, Institut for Statskundskab, Syddansk Universitet, skh@sam.sdu.dk]

Demokratiet bygger på, at borgerne er frie og selvstyrende. Med andre ord skal borgerne vælge politikere til at repræsentere sig i landets lovgivende og regerende organer. Hvis borgerne skal foretage oplyste valg, har de brug for troværdig information om væsentlige samfundsmæssige problemstillinger, og særligt om hvordan politikerne håndterer dem. Netop derfor spiller journalistikken en central og ofte omdiskuteret - rolle i demokratiet. På den baggrund er undersøgelser af journalistikkens udvikling og betingelser væsentlige, ikke bare for dem, der har en særlig interesse i journalistik, men for demokratiske samfund som helhed.

Det gælder særligt i en tid, hvor fremvæksten af internettet på flere måder udfordrer journalistikken. Journalister skal beherske flere tekniske aspekter, publicere mere på flere platforme og som regel med kortere deadlines. Samtidig er annoncemarkedet, som har været grundlag for en stor del af mediernes indtjening, i faretruende grad bevæget sig væk fra medierne til andre steder på internettet.

Derfor kan man kun glæde sig over en bog, som bygger på en omfattende komparativ undersøgelse af journalisters arbejdsforhold, idealer og praksis i tre forskellige lande, nemlig Sverige, Polen og Rusland. Særligt må man bifalde, at to af landene er østeuropæiske, da journalistikforskningen i mange år har haft kikkerten skarpest indstillet på lande $\mathrm{i}$ den såkaldt vestlige verden.

Nygren og Dobek-Ostrowska skitserer i bogens første kapitel de udfordringer, journalistikken står over for, og de fremhæver klogt, at disse udviklinger kan påvirke journalister og journalistikken forskelligt i forskellige lande. Eksempelvis har veletablerede demokratier og nyere, mindre veletablerede demokratier, temmeligt forskellige udgangspunkter for journalistikken. De efterfølgende analyser er baseret på spørgeskemaundersøgelser blandt et udsnit på 500 af journalisterne i hvert af de tre lande samt kvalitative interview med 20 journalister i hvert af de tre lande. Dette grundige empiriske arbejde er helt klart en af bogens største styrker. Vi bliver præsenteret for en stormflod af empiriske resultater, der sammenligner journalisternes svar på tværs af landene. Det er for omfattende at gå ind i hver enkelt af analyserne her, men der er en guldmine af resultater at grave $\mathrm{i}$ for forskere og studerende, der interesserer sig for og skal skrive om den journalistiske profession og 
dens udfordringer. Især supplementet med de kvalitative interview giver analyserne en ekstra dimension.

Stormfloden af resultater og sammenligninger bliver dog på sin egen måde også bogens svaghed. Man risikerer simpelthen at drukne i de mange resultater. Ikke alene bliver nogle af tabellerne, hvor resultater brydes ned på både lande og alder, temmeligt uoverskuelige, men ind i mellem taber man også det større perspektiv i sammenligningerne af syne. Det skyldes egentlig ikke så meget analyserne i de enkelte kapitler, men mere hvordan det overordnede argument præsenteres i bogens første del.

Det skyldes især, at en stor del af argumentationen - og flere af de formulerede hypoteser i indledningen - er baseret på udviklinger over tid. Empirien er dog en sammenligning af journalister på tværs af lande og ikke over tid. Dermed bliver sammenhængen mellem en del af det overordnede argument og empirien problematisk. Og godt nok er der nogle spørgsmål om udviklinger over tid i analyserne, men problemet med disse spørgsmål er, at de bygger på journalisternes opfattelse af udviklinger. Forskning viser, at disse opfattelser ofte vil være upræcise og ofte snarere et udtryk for nuværende holdninger end reelle udviklinger. Det ofte ironisk anvendte udtryk »alt var bedre i gamle dage« rummer den sandhed, at man skal passe på med for bastante fortolkninger af svar på retrospektive spørgsmål.

Man savner samtidig en grundigere teoretisering over, hvilke ligheder og forskelle man kan forvente at finde mellem de journalistiske kulturer $i$ de tre lande. Eksempelvis peger den første hypotese på, at man kan forvente at finde stigende ligheder på tværs af de tre lande, mens den næste peger på, at lighederne er overfladiske, og at der baseret på nationale traditioner og kulturer opretholdes væsentlige forskelle mellem de journalistiske kulturer i de tre lande. Lidt polemisk formuleret sidder man tilbage med indtrykket af, at man kan forvente at finde ligheder og forskelligheder, når man sammenligner forskellige lande. Så er man ligesom helgarderet, men omvendt har man ikke fået en klar retning på det argument, som analyserne skal støtte eller afkræfte. Det betyder, at hvor interessante resultaterne end er, så er det nogle gange svært at hitte rede $\mathrm{i}$, hvad sammenligningen mellem journalisterne i de tre lande mere overordnet kan lære os om den eller de journalistiske professioner og kulturer i forskellige typer af lande.

Omvendt skal bogens redaktører roses for deres sammenfatning i bogens sidste kapitel, hvor de baseret på de omfattende analyser ridser forskelle og ligheder op i forhold til journalisterne som social gruppe, journalisternes idealer og journalisternes praksis. De diskuterer blandt andet, hvordan der trods ligheder i støtten til at være neutral reporter (en form for objektivitetsnorm) er stærkere og mere veletablerede grænser for professionen i Sverige, hvor der er en lang demokratisk tradition og dermed også tradition for pressefrihed. I Sverige oplever journalisterne også forholdsvis lav indflydelse på deres daglige arbejde fra politiske aktører, mens den kommercielle indflydelse er høj. Omvendt er oplevelsen i Rusland blandt journalister overordnet set høj politisk indflydelse og lavere kommerciel indflydelse. Det illustrerer pointen om, at den politiske og markedsmæssige kontekst i de enkelte lande er væsentlig for at forstå den journalistiske kultur. 
Med deres opsamling af resultaterne og deres refleksioner og diskussioner lykkedes det således redaktørerne at sætte lighederne og forskellene mellem journalisterne $\mathrm{i}$ de tre lande ind $\mathrm{i}$ en kontekst, så man får mere ud af sammenligningen end blot de mange resultater, der bliver præsenteret i de enkelte kapitler. Samtidig må man huske at rose ambitionen i et projekt, der sammenligner journalister på tværs af lande, og det store arbejde med at samle empiri i tre forskellige lande. Bogen er således uomgængelig for enhver, der i fremtiden vil undersøge journalister i disse tre og andre lignende lande. 